(1/225) trường hợp di căn phổi sau khi hóa ác thành Sarcôm xương[2].

Hầu hết các trường hợp di căn được phát hiện trong vài năm sau chẩn đoán, măc dù di căn có thể không tìm thấy trong 10 năm hoặc hơn. Một số tác giả cho rằng di căn là do phẫu thuật viển gây gieo rắc tế bào bướu vào mạch máu và phổi khi phẫu thuât ban đâu. Tuy nhiển, môt số trong trường hợp trong y văn đã cho thấy các tổn thương ở phổi được phát hiện đồng thời hoặc ngay cả trước khi phát hiện bướu nguyên phát. Theo Rock và Campanna có vẻ hơp lý hơn về khả năng gieo rắc tế bào bướu lúc phẩu thuật là do áp lực tại chổ làm cho tế bào bướu đi vào xoang tĩnh mạch của nền bướu do nạo, mài và hoặc di căn là kết quả xâm lấn ban đâu của bướu nguyên phát như được chứng minh bởi giai đoạn của bệnh và có lẻ về kiểu gen của tế bào[6]. Nghiên cứu của chúng tôi chưa ghi nhận trường hợp BĐB xương nào di căn hoăc tử vong, có lẽ do thời gian theo dõi của chúng tôi ngắn.

\section{KẾT LUẬN}

Tỉ lệ tái phát sau điều trị BĐB đâu dưới xương quay là 4\%, không có trường hợp bị hóa ác, di căn hay tử vong. Cân có nghiên cứu thực hiện với thời gian theo dõi lâu hơn.
TÀI LIỆ THAM KHẢO

1. Lê Chí Dũng (2003) Bướu xương: Lâm sàngHình ảnh Y học- Giải phẫu bệnh và Điều trị,

2. Nguyê̂n Văn Thắng, Lê Chí Dũng (2005) "Điều trị bướu đại bào xương". Tạp chí Y học Tp.HCM, vol.9, phụ bản số 1 , tr. 155-161.

3. Chung DW, Han CS, Lee JH, Lee SG (2012) "Outcomes of wrist arthroplasty using a fre vascularized fibular head graft for enneking stage ii giant cell tumors of the distal radius". Microsurgery, doi 10.1002/micr, pp.1-7.

4. Liu YP, Li KH, Sun BH (2012) "Which Treatment is the Best for Giant Cell Tumors of the Distal Radius? A Meta-analysis.". Clin Orthop Relat Res, 470, 2886-2894.

5. Rock MG, Pritchard DJ, Unni KK (1984) "Metastases from histologically benign giant-cell tumor of bone". The Journal of Bone and Joint surgery, 66(2), 269-274.

6. Rock MG, Campanna R (1993) "The treatment of gaint cell tumor of bone". advances in operative orthopedics, Mosby- yearbook inc, St Louis, 1, pp.367-390.

7. Theresa J.C. Pazionis, Hussain Alradwan (2013) "A Systematic Review and Meta-Analysis of En-Bloc vs Intralesional Resection for Giant Cell Tumor of Bone of the Distal Radius". The Open Orthopaedics Journal, 7, 103-108.

8. Vander Griend RA, Funerburk CH (1993) "The treatment of giant cell tumors of the distal part of the radius". JBJS, 75A(6), 899- 908.

\title{
NGHIÊN CỨU TỶ LÊ MANG KHÁNG THỂ KHÁNG VIÊM GAN VI RÚT A VÀ E TRONG HUYẾT THANH CỦA NHÂN VIÊN HẬU CẦN TẠI BỆNH VIỆN TRUNG ƯƠNG QUÂN ĐộI 108
}

\section{TÓM TẮT}

Tiến hành nghiên cứu tỷ lệ mang kháng thể kháng vi rút viêm gan $A(H A V)$ sau đây gọi là kháng thể viêm gan $A$ và vi rút viêm gan $E$ (HEV) trong huyết thanh ở nhân viên hậu cần đang làm việc tại Bệnh viện Trung ương quân đôii 108 cho thấy: Tỷ lề có anti-HAV IgG dương tính chung cho các nhóm đối tượng trên là $59,25 \%$. Trong đó nhóm nhân viên nấu ẳn $73,68 \%$; Nhóm nhân viên lái xe là $50,0 \%$; Nhóm nhân viên sửa chữa điên nước là $52,63 \%$. Tý lệ có anti-HAV IgM dương tính chung cho nhóm đối tượng trên là 2,77\%. Trong đó nhóm nhân viên nấu ăn 5,26\%; Nhóm nhân

*Bênh viên Trung ương quân đôi 108

Chịu trách nhiệm chính: Nguyễn Thị Tuấn

Email: Ngthtuan1974@gmail.com

Ngày nhận bài: 5.01.2021

Ngày phản biện khoa học: 10.3.2021

Ngày duyệt bài: 18.3.2021
Nguyễn Thị Tuấn*, Lê Thanh Sơn*, Nguyễn Thị Duyên*, Nguyễn Thị Thắm*

viên lái xe là 3,12\%; Nhóm nhân viên sửa chữa điện nước là $0 \%$. Tý lệ có anti-HEV IgG dương tính chung cho nhóm đối tượng trên là $16,66 \%$. Trong đó nhóm nhân viên nấu ăn $26,31 \%$; Nhóm nhân viển lái xe là $18,75 \%$; Nhóm nhân viên sửa chữa điện nước là $5,26 \%$. Tỷ lệ có anti-HEV IgM dương tính chung cho nhóm đối tượng trên là 1,85\%. Trong đó nhóm nhân viên nấu ăn 2,63\%; Nhóm nhân viên lái xe là $0 \%$; Nhóm nhân viên sửa chữa điện nước là 2,63\%.

Tư khóa: Viêm gan A, E

\section{SUMMARY}

RESEARCH ON THE RATE OF CARRYING ANTIANTIBODIES TO HEPATITIS A VIRUS (HAV) AND HEPATITIS E VIRUS (HEV) IN SERUM IN LOGISTICS STAFF WORKING AT 108 CENTRAL MILITARY HOSPITAL

Research on the rate of carrying anti- antibodies to hepatitis A virus (HAV) and hepatitis E virus (HEV) in serum in logistics staff working at 108 Central Military 
Hospital showed: The rate of positive anti-HAV IgG for the above groups is $59.25 \%$. In that group of cooking staff $73.68 \%$; Driver staff group is $50.0 \%$; Group of electricity and water repair workers is $52.63 \%$. The rate of anti-HAV IgM positive in general for the above group of subjects was $2.77 \%$. In which the group of cooking staff is $5.26 \%$; The driver group is $3.12 \%$; Group of electricity and water repair workers is $0 \%$. The overall prevalence of positive anti-HEV IgG for the above population was $16.66 \%$. In that group of cooking staff $26.31 \%$; Driver staff group is $18.75 \%$; Group of electricity and water repair workers is $5.26 \%$. The prevalence of positive anti-HEV IgM in the above population was $1.85 \%$. In that group of cooking staff 2.63\%; The driver group is $0 \%$; Group of electricity and water repair workers is $2.63 \%$.

Keywords: Hepatitis A, E

\section{I. ĐĂT VẤN ĐỀ}

Viê̂t Nam là đất nước có tỷ lê nhiễm viên gan A, E cao do vệ sinh ăn uống cũng như đảm bảo vệ sinh nguồn nước vẫn chưa được tốt.

Cho đến nay, viêm gan $A$ đã có vắc xin phòng ngừa, viêm gan $E$ chưa có vắc xin phòng ngừa, người mắc bệnh cũng không có miễn dịch lâu dài với bệnh nên có nguy cơ tái phát lại nếu ăn phải thức ằn, hay uống nước bị nhiễm virus viêm gan $\mathrm{A}, \mathrm{E}$. Nhân viên hậu cần là những đối tượng làm các công việc như nấu ăn, lái xe, sửa chữa điện nước, những người tiếp xúc với các nguồn lâyy nhiễm cao và dễ lây sang cho các đối tượng khác của bệnh viện, chính vì thế chúng tôi nghiên cứu đề tài "Nghiên cứu tỷ lệ mang kháng thể viêm gan vi rút $A$ và $E$ trong huyêt thanh của nhân viên hậu cần tại Bệnh viện Trung ương Quân đội 108" nhằm mục tiêu xác định tỷ lệ mang kháng thể của viêm gan vi rút $A, E$ để có kế hoạch tiêm phòng và biện pháp phòng ngừa chuẩn cho các đối tượng trển khi tham gia phục vụ cho nhân viện và bệnh nhân bệnh viện.

\section{II. ĐỐI TƯợNG VÀ PHƯƠNG PHÁP NGHIÊN CỨU}

2.1. Đối tượng. 108 nhân viên hậu đang công tác tại Bệnh viện TWQĐ 108 gồm các nhóm: 38 nhân viên nấu ăn; 32 nhân viên lái xe; 38 nhân viên điện nước.

\subsection{Phương pháp}

- Nghiên cứu mô tả cắt ngang.

- Tiến hành nghiên cứu:

+ Quân Y D Bệnh viện chỉ định trên phần mềm VIMES các xét nghiệm Anti-HAV IgG, AntiHAV IgM, Anti-HEV IgG, Anti-HEV IgM cho các đối tượng trên;

+ Thu thập $2 \mathrm{ml}$ máu toàn phần bệnh nhân, tách huyết thanh, đưa mẫu vào chạy trên hệ tự động Architect i2000 (Abbott- Mỹ) theo qui trình kỹ் thuật của khoa Miễn dịch. Phương pháp xét nghiệm hóa phát quang tự động, theo nguyên lý Sandwich và cạnh tranh.

- Kết quả được in ra sau đó mang đi xử lý số liệu.

2.3. Xử lý số liệu

- Phân tích có ý nghĩa thống kê khi $p<0,05$.

- Các thông số biểu diễn dưới dạng n (\%), tính toán theo thuật toán thống kê bằng phần mềm SPSS 21.0.

\section{KẾT QUẢ NGHIÊN CỨU}

\section{1. Đặc điểm chung}

Bảng 1: Đặc điếm chung các nhóm nghiên cứu

\begin{tabular}{|c|c|c|c|}
\hline Đặc điểm & $\begin{array}{c}\text { Số } \\
\text { lượng }\end{array}$ & $\begin{array}{c}\text { Tỷ lệ } \\
\text { \%o }\end{array}$ & P \\
\hline Nam & 48 & 44,44 & $<0,05$ \\
\hline Nữ & 60 & 55,6 & $<0,05$ \\
\hline $\begin{array}{c}\text { Tuối (trung bình } \pm \\
\text { độ lệch chuẩn) năm }\end{array}$ & \multicolumn{2}{|c|}{$35,65 \pm 15,63$} & $<0,05$ \\
\hline
\end{tabular}

Nhân xét. Nghiên cứu của chúng tôi có 108 nhân viên, nữ chiếm 56,7\%; nam chiếm 43,3 \%. Tuổi trung bình 35,6 \pm 17,63 năm.

3.2. Tỷ lệ mang kháng thể anti-HAV IgG của các nhóm nhân viên

Bảng 2: Tỷ lệ mang kháng thể anti-HAV IgG của các nhóm nhân viên

\begin{tabular}{|c|c|c|c|}
\hline Đối tượng & $\begin{array}{c}\text { Số mắc/ } \\
\text { tổng số }\end{array}$ & $\begin{array}{c}\text { Tỷ lệ } \\
\text { \%o }\end{array}$ & P \\
\hline Nhóm nhân viên nấu ăn & $28 / 38$ & 73,68 & $>0,05$ \\
\hline Nhóm nhân viên lái xe & $16 / 32$ & 50,0 & $>0,05$ \\
\hline $\begin{array}{c}\text { Nhóm sưa chữa điện, } \\
\text { nước }\end{array}$ & $20 / 38$ & 52,63 & $>0,05$ \\
\hline Tống số nhân viên & $64 / 108$ & 59,25 & $>0,05$ \\
\hline
\end{tabular}

Nhận xét: Nghiên cứu của chúng tôi thây tỳ lệ mang anti-HAV IgG cao nhất ở nhóm nhân viên nấu ăn, thấp nhất ở nhóm nhân viên lái xe.

3.3. Tỷ lệ mang kháng thể anti-HAV IgM của các nhóm nhân viên

Bảng 3: Tỷ lệ mang kháng thể anti-HAV IgM của các nhóm nhân viên

\begin{tabular}{|c|c|c|c|}
\hline Đối tượng & $\begin{array}{c}\text { Số má măc/ } \\
\text { tống số }\end{array}$ & $\begin{array}{c}\text { Tỷ lệ } \\
\text { \% }\end{array}$ & $\mathbf{P}$ \\
\hline Nhóm nhân viên nấu ăn & $2 / 38$ & 5,26 & $>0,05$ \\
\hline Nhóm nhân viên lái xe & $1 / 32$ & 3,12 & $>0,05$ \\
\hline Nhóm sứa chữa điện, nước & $0 / 38$ & 0 & $>0,05$ \\
\hline Tống số nhân viên & $3 / 108$ & 2,77 & $>0,05$ \\
\hline
\end{tabular}

Nhận xét: Theo nghiên cứu thấy tỷ lệ mang anti-HẢV IgM của nhóm nhân viên nấu ăn là $5,26 \%$, nhóm nhân viên sửa chữa điện nước không có ai mắc bệnh.

3.4. Tỷ lệ mang kháng thể anti-HEV IgG của các nhóm nhân viên

Bảng 4: Tỷ lệ mang kháng thể anti-HEV IgG của các nhóm nhân viên 


\begin{tabular}{|c|c|c|c|}
\hline Đối tượng & $\begin{array}{c}\text { Số măc/ / } \\
\text { tổng số }\end{array}$ & $\begin{array}{c}\text { Tỷ lệ } \\
\text { \% }\end{array}$ & P \\
\hline Nhóm nhân viên nấu ăn & $10 / 38$ & 26,31 & $>0,05$ \\
\hline Nhóm nhân viên lái xe & $6 / 32$ & 18,75 & $>0,05$ \\
\hline Nhóm sửa chữa điện, nước & $2 / 38$ & 5,26 & $>0,05$ \\
\hline Tống số nhân viên & $18 / 108$ & 16,66 & $>0,05$ \\
\hline
\end{tabular}

Nhận xét: Theo nghiên cứu thấy tỷ lệ mang anti-HEV IgG của nhóm nhân viên nấu ăn là cao nhất 26,31\%, nhóm nhân viên sửa chữa điện nước có tỷ lệ là 5,26\% thấp nhất.

3.5. Tỷ lệ mang kháng thể anti-HEV IgM của các nhóm nhân viên

Bảng 5: Tỷ lệ mang kháng thể anti-HEV IgM của các nhóm nhân viên

\begin{tabular}{|c|c|c|c|}
\hline Đối tượng & $\begin{array}{l}\text { Số mắc/ } \\
\text { tổng số }\end{array}$ & $\begin{array}{c}\text { Tỷ lệ } \\
\text { \% }\end{array}$ & $\mathbf{P}$ \\
\hline Nhóm nhân viên nấu ăn & $1 / 38$ & 2,63 & $>0,05$ \\
\hline Nhóm nhân viên lái xe & $0 / 32$ & 0 & $>0,05$ \\
\hline Nhóm sứa chữa điện, nước & $1 / 38$ & 2,63 & $>0,05$ \\
\hline Tống số nhân viên & $2 / 108$ & 1,85 & $>0,05$ \\
\hline
\end{tabular}

Nhận xét: Theo nghiên cứu thấy tỷ lệ mang anti-HEV IgM của nhóm nhân viên nấu ăn và nhóm nhân viên sửa chữa điện, nước là 2,63\%, nhóm nhân viên lái xe không có ai mắc bệnh.

\section{BÀN LUÂN}

4.1. Bàn luận về tỷ lệ mang kháng thể viêm gan A. Anti- HAV là kháng thể do cơ thể tạo ra khi bị nhiễm virus gây viêm gan siêu vi $A$ (HAV). Trong đợt nhiễm cấp (mới nhiễm) thì cơ thể tạo ra loại kháng thể IgM (Anti- HAV IgM), qua đợt cấp thì cơ thể tao ra loại kháng thể IgG (Anti- HAV IgG) và khi đó anti- HAV IgM sẽ mất đi. Anti- HAV Total là gồm cả IgG và IgM, nên chỉ số này dương tính cho biết bạn có nhiễm HAV.

HAV là bênh lây theo đường tiêu hóa qua thức ăn, nước uống nhiễm HAV. Bệnh thường khỏi hoàn toàn và không có tổn thương lâu dài. Sau khi nhiễm vi rút viêm gan $A$ thì thường người đã bị nhiễm có miễn dịch suốt đời.

ở vùng lưu hành cao, một số nước ở châu Á, châu Phi, Mỹ Latinh và Trung Đông, tỷ lệ kháng thể anti-HAV IgG đạt $90 \%$ ở người lớn, và hầu hết trẻ em 10 tuổi đã bị nhiễm. Ỡ vùng lưu hành trung bình, một số nước ở châu Á và châu Âu, chỉ có $50 \%-60 \%$ người lớn và $20 \%-30 \%$ trẻ em 10 tuổi đã bị lây nhiễm. Ở vùng lưu hành dịch thấp, chỉ có $30 \%$ người trưởng thành có kháng thể anti-HAV. Đối tượng nhiểm hay gặp nhất trong lứa 5 - 14 tuổi. Tại Bệnh viện TWQĐ 108 lứa tuổi trung bình trong nghiên cứu là $35,65 \pm$ 15,63 năm đây là những người trưởng thành nên tỷ lệ mắc bệnh hay mang kháng thể là thấp hơn rất nhiều.

Với tỷ lệ mang kháng thể anti-HAV IgG chung là $59,25 \%$ của các nhóm nhân viên Hậu cân Bệnh viện TWQĐ 108 nằm trong vùng lưu hành trung bình của bênh viêm gan $A$. Vì hầu hết những người trưởng thành đã có kháng thể tự nhiên bảo vệ chống lại bệnh viêm gan $A$ suốt đời nên nhóm này không cẩn tiêm phòng vắc xin. Tuy nhiên có thể vẫn bị tái nhiễm HAV, gây viêm gan $\mathrm{A}$ tái nhiễm. Những trường hợp này cần điều trị nhất là khi có tỷ lệ 2,77\% HAV IgM dương tính. Còn những trường hợp HAV IgG âm tính cần tiêm phòng vắc xin, hiện nay đã có vaccine phòng bệnh viêm gan $A$ hiệu quả và an toàn.

Tóm lại kết hợp cả 2 loại xét nghiệm HAV Ab có thể gặp các trường hợp:

\begin{tabular}{|c|c|c|}
\hline & HAV IgG (-) & HAV IgG + \\
\hline $\begin{array}{l}\text { HAV } \\
\operatorname{IgM}(-)\end{array}$ & $\begin{array}{l}\text { - Không bị nhiếm } \\
\text { HAV } \\
\text { - Chưa tiêm vắc xin } \\
\text { phòng bênh hoắc } \\
\text { vắc xin không đá̉p } \\
\text { ứng với cơ thể }\end{array}$ & $\begin{array}{l}\text { - Đã từng nhiếm } \\
\text { HAV } \\
\text { - Đang nhiễm } \\
\text { HAV cấp tính } \\
\text { - Đã tiêm phòng } \\
\text { vắc xin }\end{array}$ \\
\hline $\begin{array}{c}\text { HAV } \\
\text { IgM + }\end{array}$ & $\begin{array}{c}\text { - Đang bị nhiếm HAV } \\
\text { - Giai đoạn sớm khi } \\
\text { cơ thể chưa sản xuất } \\
\text { ra HAV IgG }\end{array}$ & $\begin{array}{l}\text { - Đang bị nhiễm } \\
\text { HAV cấp tính }\end{array}$ \\
\hline
\end{tabular}

Một xét nghiệm tống HAV Ab dương tính cho thấy phơi nhiếm HAV trước đó nhưng không loại trừ viêm gan cấp tính hoặc rất gần đây. Xét nghiệm HAV Ab Total âm tính có nghĩa là không có phơi nhiếm với virus trước đó và nên tiêm vắc-xin viêm gan $A$. Những đường lây lan chính của virus viêm gan $A$ bao gồm:

- Ăn thức ăn chế biến bởi người bị viêm gan $A$ không rửa tay kỹ sau khi đi vệ sinh, chính vì vậy người làm nghề nấu ăn phải được kiểm tra xét nghiệm định kỳ để tránh lây lan cho người khác. - Ản chung thức ăn, đồ uống và sử dụng chung đồ dùng sinh hoat cá nhân như khăn mă̆t, khăn tắm, bàn chải đánh răng với người bệnh có thể gây lây truyền bệnh viêm gan $A$.

- Uống nước ở nguồn nước ô nhiễm;

- Ăn sò, ốc sinh sông ở nguồn nước ô nhiễm;

- Tiếp xúc thường xuyên với người bệnh viêm gan $A$;

- Quan hệ tình dục với người đang mang virus viêm gan $A$.

Chính vì những lý do trên Quân $Y \mathrm{D}$ Bệnh viện TWQĐ 108 cho kiểm tra xét nghiệm HAV các đối tượng bệnh nhân có nguy cơ trên định kỳ hàng năm.

4.2. Bàn luận về tỷ lệ mang kháng thể viêm gan $E$. Viêm gan $E$ là bệnh viêm gan cấp tính do virus HEV gây ra. Trên thế giới, bệnh viêm gan $\mathrm{E}$ xảy ra khá phổ biến. Các nhà nghiên cứu 
đã nhân định có 4 loạ gen chính của virus HEV gây bệnh, trong đó type 1 và 2 là loại chủ yếu gây bệnh ở người. Việt Nam là một trong số những quốc gia có tỷ lệ nhiễm viêm gan $\mathrm{E}$ cao, đặc biệt vào mùa mưa ở những vùng có điều kiện vệ sinh kém. Phần lớn bệnh viêm gan $\mathrm{E}$ có thể tự khỏi nếu sức đề kháng tốt, tuy nhiên mặt khác có một số trường hợp bệnh sẽ diễn biến nghiêm trọng, trở nên ác tính và đe dọa đến tính mạng.

Virus HEV thường tồn tai trong phân, chất thải rửa, nguồn nước ô nhiểm,... bám vào thực phẩm và lây truyền cho con người qua đường phân - miệng. Một số đường lây nhiễm cần chú ý của virus như:

- Ăn các thực phẩm bi nhiễm virus hoặc động vật nhiễm bênh.

- Lây nhiểm qua đường máu.

- Lây truyền từ mẹ sang con.

Nguồn nước bị ô nhiễm là điều kiện thuận lợi để phát tán virus trong cộng đồng. Do đó con người cần phải chủ động có những biện pháp phòng ngừa sự lây nhiễm của bệnh. Các triệu chứng lâm sàng của viêm gan $\mathrm{E}$ khá giống với các bệnh viêm gan do virus khác, chính vì vậy rất khó để chẩn đoán chính xác bệnh nếu chỉ dựa vào lâm sàng. Một trong những phương pháp hiệu quả để chẩn đoán viêm gan $\mathrm{E}$ chính xác đó là xét nghiệm các kháng thể IgG và IgM của virus HEV trong máu.

Anti HEV IgG là kháng thể miễn dịch của virus HEV được sinh ra khi cơ thể có sự tiếp xúc với virus. Người mang kháng thể anti HEV IgG sẽ có khả năng miễn nhiếm và không bị lây bệnh viêm gan $\mathrm{E}$. Tuy nhiên sau khoảng 5 - 10 năm, nồng độ anti HEV IgG trong máu có thể giảm dần và không mất khả năng chống lại sự xâm nhập của virus.

Trong khi đó anti HEV IgM là kháng thể tự nhiên của virus HEV và tăng cao khi bệnh có dâuu hiệu đang tiến triển. Tuy nhiên xét nghiệm anti HEV IgM được coi là kỹ thuật xét nghiệm phức tạp và đòi hỏi máy móc trang thiết bị rất hiện đại.

Các nhân viên hậu cần Bệnh viện 108 sau khi khảo sát có 1 tỷ lệ bị nhiễm viêm gan $E(1,85 \%)$ và nhóm nhân viên nấu ăn, thợ điện nước có tỷ lệ nhiễm $2,63 \%$ sẽ được cách ly tránh lây nhiễm, các nhân viên còn lại sẽ được xây dựng và duy trì thói quen rửa tay sạch sẽ trước và sau khi ăn, khi chế biến món ăn; Giữ gìn vệ sinh thân thể và các đồ dùng, vật dụng trong bếp nấu ăn cho bệnh viện, không sử dụng chung đồ vệ sinh cá nhân; Đồ ăn đảm bảo nấu chín, nước uống đun sôi tiệt trùng, hạn chế ăn rau sống, trái cây không gọt vỏ.
Bênh viêm gan $E$ tuy có thể tự khỏi nhưng nếu bệnh tiến triển cấp tính thì sẽ vô cùng nguy hiểm và gây ra nhiều biến chứng nghiêm trọng. Việc phát hiện sớm bệnh cũng giúp cho Quẩn Y D Bệnh viện chủ động có biện pháp bảo vệ tránh lây nhiễm cho cộng đồng.

\section{KẾT LUÂNN}

- Tỷ lệ mang kháng thể HAV IgG của các nhóm nhân viên nói chung là: 59,25\%

- Tỷ lệ mang kháng thể HAV IgM của các nhóm nhân viên là: $2,77 \%$

- Tỷ lệ mang kháng thể HEV IgG của các nhóm nhân viên là: $16,66 \%$

- Tỷ lệ mang kháng thể HEV IgM của các nhóm nhân viên là: $1,85 \%$

Đây là những số liệu Quân $Y \mathrm{D}$ nắm được nên có kế hoạch tiêm phòng vắc xin viêm gan $A$, có biện pháp phòng lây nhiễm viêm gan $A, E$ cho cộng đồng và tránh tái nhiễm cho nhân viên.

\section{TÀI LIÊU THAM KHẢO}

1. Ouvết đinh số $5447 / 0 \oplus-B Y T$ nqàv 19/06/ 2015 của Bô $Y$ tế về viêc ban hành Hướng dẫn chẩn đoán, điều trị bênh viêm gan vi rút $A$.

2. Quyết định số 5450/QĐ-BYT ngày $30 / 12 / 2014$ của Bộ $Y$ tế ban hành Hướng dần chẩn đoán, điều trị bệnh viêm gan vi rút $\mathrm{E}$.

3. Guyatt $\mathbf{G H}$, Oxman AD, Vist GE, Kunz $R$, Falck-Ytter $\mathbf{Y}$, Alonso-Coello $\mathbf{P}$, et al. GRADE: an emerging consensus on rating quality of evidence and strength of recommendations. BMJ 2008;336:924-926.

4. Balayan MS, Andjaparidze AG, Savinskaya SS, Ketiladze ES, Braginsky DM, Savinov AP, et al. Evidence for a virus in non- $A$, non- $B$ hepatitis transmitted via the fecal-oral route. Intervirology 1983;20:23-31.

5. Reyes GR, Purdy MA, Kim JP, Luk KC, Young LM, Fry KE, et al. Isolation of a cDNA from the virus responsible for enterically transmitted non-A, non-B hepatitis. Science 1990;247:1335-1339.

6. Smith DB, Simmonds PInternational Committee on Taxonomy of Viruses Hepeviridae Study Group, Jameel S, Emerson SU, Harrison TJ, et al. Consensus proposals for classification of the family Hepeviridae. J Gen Virol 2014;95:2223-2232.

7. Guyatt GH, Oxman AD, Vist GE, Kunz R, Falck-Ytter $\mathbf{Y}$, Alonso-Coello P, et al. GRADE: an emerging consensus on rating quality of evidence and strength of recommendations. BMJ 2008;336:924-926.

8. Balayan MS, Andjaparidze AG, Savinskaya SS, Ketiladze ES, Braginsky DM, Savinov AP, et al. Evidence for a virus in non- $A$, non- $B$ hepatitis transmitted via the fecal-oral route. Intervirology 1983;20:23-31.

9. Smith DB, Simmonds PInternational Committee on Taxonomy of Viruses Hepeviridae Study Group Jameel S, Emerson SU, Harrison TJ, et al. Consensus proposals for classification of the family Hepeviridae. J Gen Virol 2014;95:2223. 